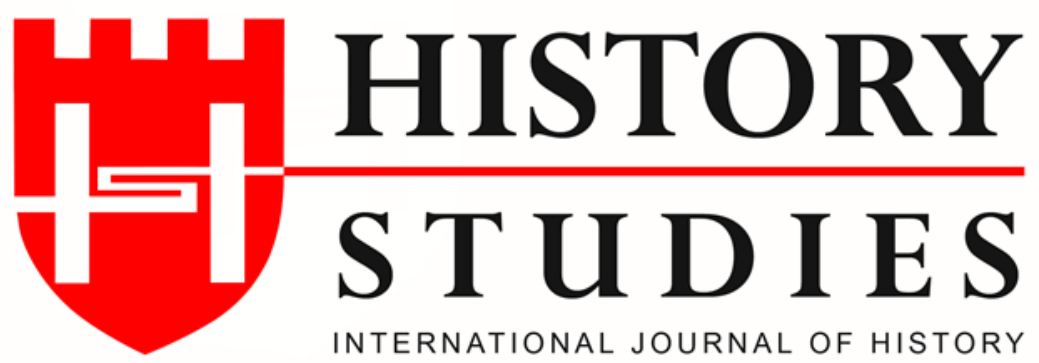

ISSN: 13094173 / (Online) 1309 - 4688 (Print)

Volume: 13, Issue: 5, October 2021

www.historystudies.net

\title{
THE IMPORTANCE OF GENOA PORT IN THE COMPETITION BETWEEN THE ITALIAN AND FRENCH NAVY IN THE MEDITERRANEAN BEFORE THE FİRST WORLD WAR ACCORDING TO CONSULATE REPORTS
}

Şehbender Raporlarına Göre Birinci Dünya Savaşı Öncesinde Akdeniz’de İtalyan ve Fransız Donanmaları Arasındaki Rekabette Cenova Limanı'nın Önemi

\author{
Dr. Öğrt. Üyesi Ozan Tuna \\ Milli Savunma Üniversitesi \\ otuna@msu.edu.tr \\ ORCID ID: 0000-0003-4762-4286
}

\author{
Makale Türü-Article Type : Araştırma Makalesi-Research Article \\ Geliş Tarihi-Received Date : 07.092021 \\ Kabul Tarihi-Accepted Date : $\quad \mathbf{2 6 . 1 0 . 2 0 2 1}$ \\ DOI Number : 10.9737/hist.2021.1053
}

Atıf-Citation:

Ozan Tuna, "The Importance of Genoa Port in the Competition Between the Italian and French Navy in the Mediterranean Before the First World War According to Consulate Reports", History Studies, 13/5, Ekim 2021, s. 16651673. 

HISTORY STUDIES

Uluslararası Tarih Araştırmaları Dergisi International Journal of History

13/5, Ekim - October 2021

1665-1673

Araştırma Makalesi

\section{THE IMPORTANCE OF GENOA PORT IN THE COMPETITION BETWEEN THE ITALIAN AND FRENCH NAVY IN THE MEDITERRANEAN BEFORE THE FIRST WORLD WAR ACCORDING TO CONSULATE REPORTS}

Şehbender Raporlarına Göre Birinci Dünya Savaşı Öncesinde Akdeniz'de İtalyan ve Fransız Donanmaları Arasındaki Rekabette Cenova Limanı'nın Önemi

\section{Dr. Öğrt. Üyesi Ozan Tuna}

\section{$\ddot{O} z$}

Cenova limanı yirminci yüzyılın başları itibariyle İtalyan donanması için önem kazanmaya başlamış olup donanmasına günden güne daha fazla yatırım yapan İtalya'nın gerek Birinci Dünya Savaşı öncesinde Fransa ile yaşadığı Akdeniz rekabeti gerekse Almanya ile tesis ettiği askeri ittifak Cenova'yı daha da önemli bir liman haline getirmiştir. Osmanlı Devleti ise Trablusgarp Savaşı'nın (1911-1912) ardından bir taraftan İtalya ile münasebetlerini geliştirmeye çalışmakta iken diğer taraftan da şehbenderleri vasıtasıyla İtalyan donanmasının faaliyetlerini takip etmeye başlamıştır. Özellikle Birinci Dünya Savaşı öncesindeki silahlanma yarışının en belirgin hale geldiği dönem olan 1914 yılının ilk yarısında İtalyan donanmasının Doğu Akdeniz'e yönelik herhangi bir girişimi Osmanlı Devleti tarafından dikkatle izlenmiştir. Bu bağlamda çalışmamızda 1914 yılının şehbender raporları 1şığında Cenova limanının askeri yapısı incelenmiş olup İtalyan donanmasının Fransız donanması ile gerçekleştirdiği Akdeniz'deki donanma rekabeti bağlamında da bu limanın yeri ve önemi tespit edilmeye çalışılmıştır.

Anahtar Kelimeler: Akdeniz, Adriyatik Denizi, Marsilya Limanı, Ansaldo

\section{Abstract}

The port of Genoa started to gain importance port he Italian navy at the beginning of the twentieth century, and Italy, which invested more in its navy day by day, both the Mediterranean rivalry with France before the First World War and the military alliance it established with Germany made Genoa an even more important port. While the Ottoman Empire was trying to improve its relations with Italy after the Tripoli War (1911-1912), on the other hand, it started to follow the activities of the Italian navy through its consulates. Especially in the first half of 1914, when the arms race before the First World War became most evident, any attempt of the Italian navy towards the Eastern Mediterranean was carefully followed by the Ottoman Empire. In this context, in our study, the military structure of the Genoa port was examined in the light of the consulate reports of 1914, and the place and importance of this port were tried to be determined in the context of the naval competition of the Italian navy with the French navy in the Mediterranean.

Keywords: Mediterranean Sea, Adriatic Sea, Marseille Port, Ansaldo 


\title{
Introduction
}

When we look at the power struggles before the First World War, it was seen that especially the seas became a competition area for many states, and in this context, the west of the Mediterranean became a competition area between the Italian and French navies. Although the French navy had been active in the Mediterranean for centuries and was allied with the British navy, it could not prevent the rise of the Italian navy, and therefore the Italian navy came up against itself as a strong rival. Before the First World War, Britain's decrease in its military power in Malta and Germany's creation of the Mediterranean fleet in 1912 constituted a great advantage for the central states (Germany, Austro-Hungarian Empire and Italy), and this new situation especially affected the Italian navy and contributed to the expansion of its area. ${ }^{1}$ In the light of these developments, the Mediterranean strategy of the central states was shaped by the end of 1913, and in the event of a world war, it was aimed to eliminate the connection between Algeria and the French mainland by pushing the French navy out of the war after the warships of all three states came together in the port of Messina, Italy. In this planning, the port of Genoa, located at a very critical point in the west of the Mediterranean, became an important center of gravity in the context of the Italian navy's operation, and the fortification of the region by the Italians was also important in terms of determining the course of the war.

In this respect, in our study, the military structure of the port of Genoa was examined according to the Ottoman consul reports at a time when the central states were planning a war against the French navy in the Mediterranean, and the strategic importance of the port of Genoa, which is at a very important point due to its location in this power struggle planned to take place in the west of the Mediterranean, was tried to be determined.

\section{A General Assessment on the Structure of the Italian Navy Before the First World War}

Italy, which started the arms race rapidly after completing its union at the end of the nineteenth century, accelerated the modernization of its navy, especially with the gaining importance of armored warships, and built Duilia, Dantolo and Lepanto class warships with a weight of 11,000 to 13,000 tons in the first place. ${ }^{2}$ Italy, which could effectively use its military power in its navy during the Tripoli War, on the one hand bombarded the Beirut port and the Dardanelles and captured the Dodecanese Islands, on the other hand, managed to impose a blockade against the Ottoman Empire in the Red Sea, the Eastern Mediterranean and the Aegean Sea. ${ }^{3}$ After the Tripoli War, the Italian navy, which supported the international fleet that imposed a blockade on the coasts of this state due to the Montenegrin problem in the Adriatic Sea, actively supported this operation with three warships. ${ }^{4}$

\footnotetext{
${ }^{1}$ Politisches Archiv des Auswärtigen Amts, RZ 201 / 8091, Sayfa No: 23, 21 Mayıs 1913.

${ }^{2}$ Poul G. Halpern, The Mediterranean Naval Situation 1908-1914, Harward University Press, USA 1971, p. 187.

3 İsrafil Kurtcephe, Türk-İtalyan Ilişskileri (1911-1916), Türk Tarih Kurumu Yayınları, Ankara 1995, s. 100-101; Sezen Kılıç, Trablusgarp Savaşı’nda İtalyan Donanmasının Çanakkale Boğazı Harekâtı (Alman Belgelerine Göre), Türk Tarih Kurumu Yayınları, Ankara 2018, s. 34; Nuri Karataş, "Askeri ve Siyasi Yönleriyle İtalyan Donanmasının Çanakkale Boğazı Harekâtı (18 Nisan 1912)”, Akademik Bakış, Say1 12 (2013), c. 6, s. 95; Illustrierte Kronen Zeitung, "Der Italienische Ueberfall auf der Hafenstadt Beirut", Sayfa No: 1, 28 Şubat 1912.

${ }^{4}$ Das Interessante Blatt, "Der Beschluß der Mächte über die Flottendemonstration”, Sayfa No: 11, 10 Nisan 1913.
}

\author{
History Studies \\ www.historystudies.net
}




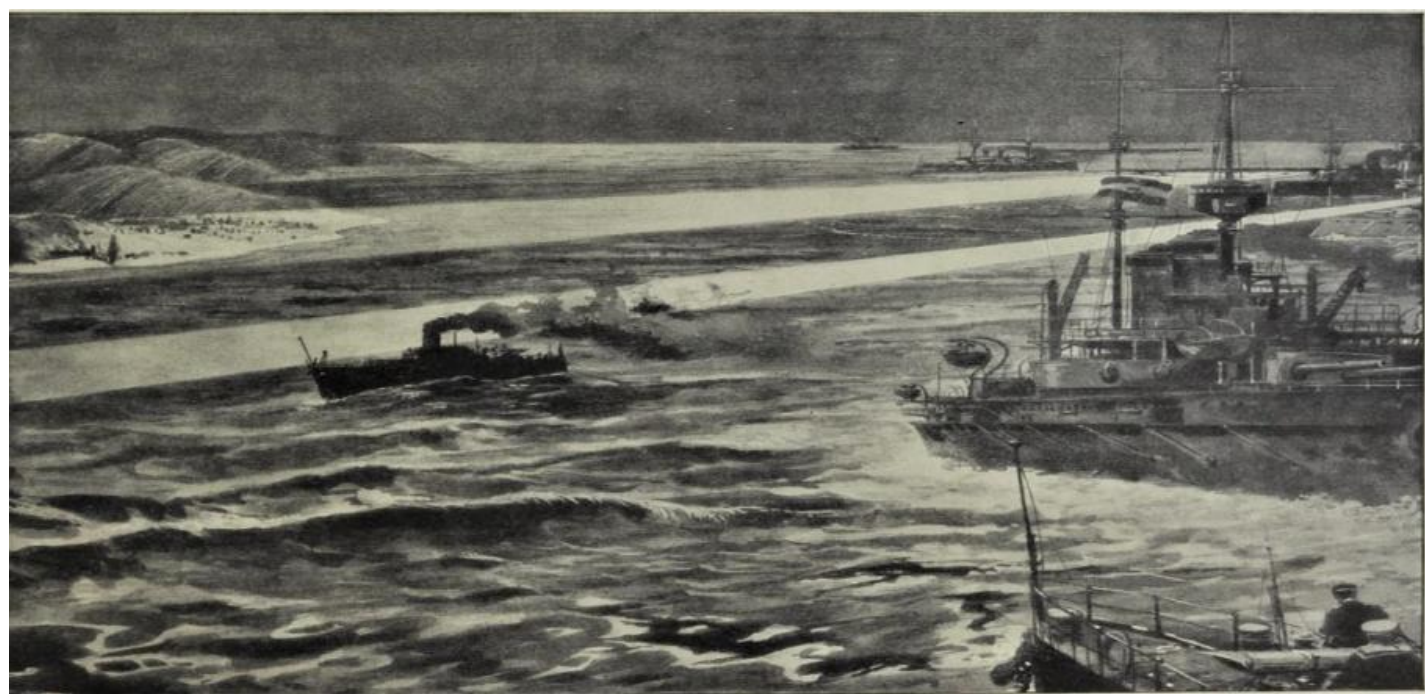

Illustration 1: The blockade of the Montenegrin coast by the international fleet, including the Italian navy $^{5}$

Before the First World War, under the command of Admiral Luigi di Savoina, the Italian navy, whose main body consisted of Conte di Cavour, Dante Alegrieri, Leonardo da Vinci, Guilio Cesare, Regina, Vittorio Emanuele, Roman and Naples warships, was planning to have three dreadnoughts by the middle of 1914 and apart from the ports of Genoa, La Spesia, Brindzi, Venice, it had the most effective fighting force in the Mediterranean with its points such as Tobruk and Rhodes. ${ }^{6}$ Planning to dominate the Mediterranean by acting jointly with Germany and the Austro-Hungarian Empire in an approaching world war, the Italians, despite their undeveloped industries and being vulnerable to a blockade by the enemy, with 37,500 highly motivated naval personnel against Britain and France had an effective military deterrent in the Mediterranean. ${ }^{7}$ Before the First World War, the Italian navy, which was in competition with the French navy in a wide geography from Tunisia to Marseille, was considering creating a dominance area of its own in the Mediterranean, especially with the close alliance it formed with Germany $^{8}$

Before the first World War, the British Navy's shift of some of its power in the Mediterranean to the North Sea allowed the Italian navy to use its presence in the region more effectively, and therefore the Italians decided to break France's influence in the west of the Mediterranean by acting in partnership with Germany and the Austro-Hungarian Empire. ${ }^{9}$ The fact that the Italian navy has a more effective power and dynamism than the German and Austro-Hungarian navies in terms of numbers has made this state more prominent in the competition with France, and especially the acceleration of the navy building program and the fortification of the French border

\footnotetext{
${ }^{5}$ Das Interessante Blatt, "Blockade der Küste Montenegros", Sayfa No: 1, 10 Nisan 1913.

${ }^{6}$ Otto Mielke, Torpedoboots-Zerstörer-Scharfschütze: Vom Seekrieg im Mittelmeer 1914-1918, Maximilian Varlag, Hamburg 1998, ss. 14-22; Lawrance Sondhaus, The Naval Policy of Austria-Hungary 1867-1918: Navalism, Industrial Development and Politics of Dualism, Purdue University Press, 1994, ss. 191-204; Lawrance Sondhaus, The Great War at Sea: A Naval History of the First World War, Cambridge University Press, UK 2014, s. 59; Poul G. Halpern, The Mediterrenean Naval Situation 1908-1914, ss. 202-264.

${ }^{7}$ Bundesarchiv, Militärarchiv; Nachlasse und Sammlungen, Dosya No: 156-1, Sayfa No: 8, 2 Aralık 1913; Dan Van der Vot, Dünyayı Değiştiren Gemi: Goeben'in 1914'te Çanakkale Boğazı'na Kaçışı, s. 49.

${ }^{8}$ Politisches Archiv des Auswärtigen Amts, RZ 201 / 8091, Sayfa No: 27, 10 Haziran 1912; Tanin, "Fransa Bahriye Manevraları", Sayfa No: 1, 9 Temmuz 1914.

${ }_{9}^{9}$ Politisches Archiv des Auswärtigen Amts, RZ 201 / 7835, Sayfa No: 28-29, 28 Şubat 1912.
}

\author{
History Studies \\ www.historystudies.net
}


made the Italian navy a more effective power in the west of the Mediterranean. ${ }^{10}$ As a result, the fairly modern naval power of the Italian navy, with its well-motivated personnel and adequate infrastructure, took its place as the only force that could face the French Navy in the Mediterranean before the First World War, and in this context, it planned to lock the French Navy in its ports and make the west of the Mediterranean its area of dominance. Neutralizing the French Navy in the Mediterranean would prevent this navy from sending troops from Algeria to the French mainland, as well as prevent it from going to help Britain in the North Sea, and thanks to the numerical advantage planned to occur, the German navy would achieve a decisive victory over Britain in the North Sea.

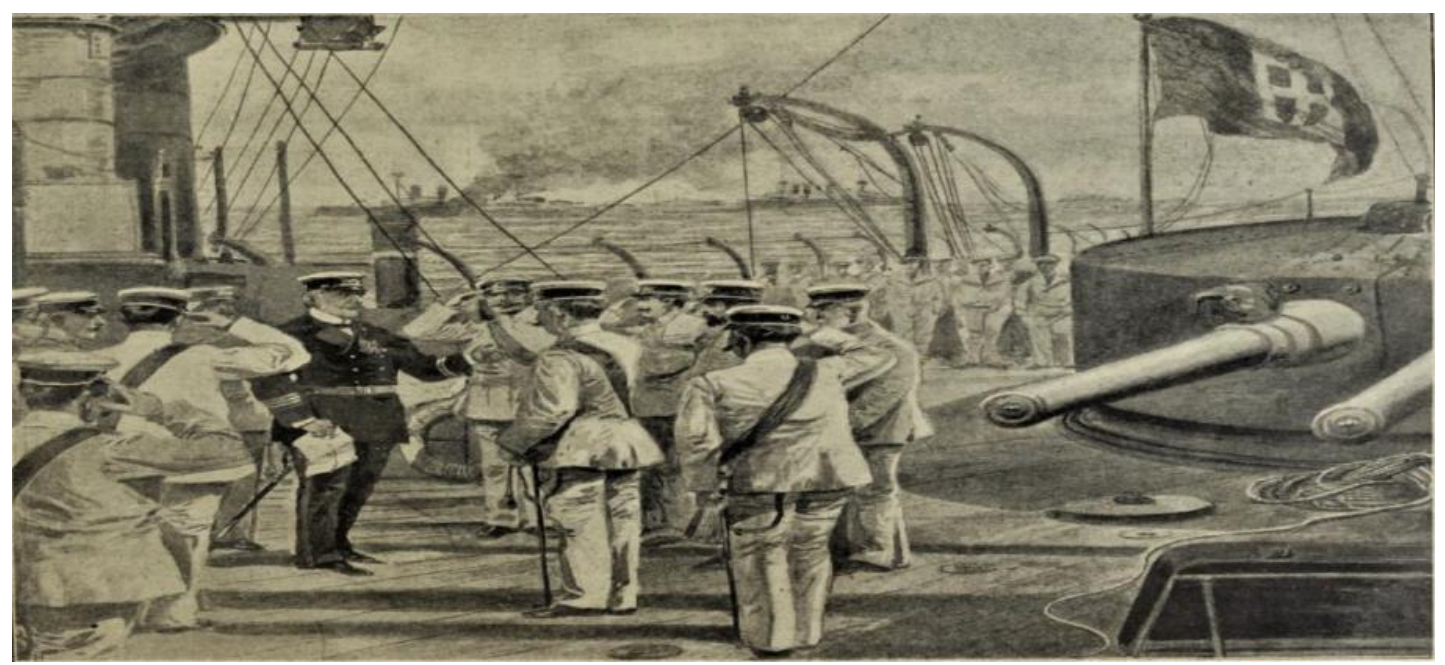

Illustration 2: Italian Navy ${ }^{11}$

\title{
2.Military Structure and Strategic Importance of the Port of Genua
}

According to information obtained from German military sources in Rome, Italy's rivalry with France in the Mediterranean became even more pronounced from November 1911, and despite this, the Italians thought it would be more appropriate to expect their dreadnoughts, built for a fight with France at sea, unlike the Germans. ${ }^{12}$ While the Germans insisted on acting jointly with the Italian and Austro-Hungarian navies in the port of Messina in a war that could break out in the Mediterranean, the Italians wanted the naval program to end until 1920 in order to engage in a full-scale struggle with the French navy. ${ }^{13}$ While the Italian military planners insisted that the naval program implemented by them should end in order to gain a numerical advantage against the French navy, they stated that otherwise the French navy would be superior to them. ${ }^{14}$ The fact that the Italian navy was not fully prepared for the war in the Mediterranean eliminated the joint fleet's idea of using the port of Genoa as an operation center, while the port of Messina in the

10 Politisches Archiv des Auswärtigen Amts, RZ 201 / 7835, Sayfa No: 38-46, 12 Nisan 1912- 21 May1s 1912; Politisches Archiv des Auswärtigen Amts, RZ 201/ 7835, Sayfa No: 107, 8 Mart 1913; Politisches Archiv des Auswärtigen Amts, RZ 201 / 7835, Sayfa No: 138, 13 Aralık 1913.

${ }^{11}$ Das Interessante Blatt, "Der Krieg zwischen Italien und der Türkei”, Sayfa No: 1, 5 Ekim 1911.

12 Politisches Archiv des Auswärtigen Amts, RZ 201 / 7835, Sayfa No: 61, 8 Haziran 1912 (Almanya'nın Roma'daki Donanma Ateşesinin Raporu)

${ }^{13}$ Politisches Archiv des Auswärtigen Amts, RZ 201 / 7835, Sayfa No: 62, 8 Haziran 1912 (Almanya'nın Roma'daki Donanma Ateșesinin Raporu)

${ }^{14}$ Politisches Archiv des Auswärtigen Amts, RZ 201 / 7835, Sayfa No: 62, 8 Haziran 1912 (Almanya'nın Roma'daki Donanma Ateşesinin Raporu)

\author{
History Studies \\ www.historystudies.net
}


middle of the Mediterranean became more prominent. In this way, it was planned that the AustroHungarian Empire navy in the Adriatic Sea and the German fleet in the east of the Mediterranean could quickly go to support the Italian navy.

The port of Genoa, which is the main subject of our article, was planned both as a supply point for the fleet that would depart from Messina for the Italians in their struggle with France, and was fortified by land and sea as it could be a direct target for the attack of the French navy. In this respect, in the consulate reports, information was given that the port was fortified with 12 and 14 $\mathrm{cm}$ guns in order to be defended from the region during the attack of the French navy, and the points where the fortifications were located were also hidden. ${ }^{15}$ While it was stated in the reports that one of the batteries was located in the middle of the port and the other in the Phare lighthouse at the end of the port, it was stated that the fortifications were insufficient, although the exact location and number of the cannons here could not be determined. ${ }^{16}$ Consulate did not mention the mine lines necessary for the defense of the port from the sea, but instead stated that the warships of the Italian navy undertook the defense of the port from the sea, but gave the information that these warships periodically carried out artillery maneuvers at points close to the French border and carried out reconnaissance-observation activities in the region. ${ }^{17}$ It is stated in the reports that it is very difficult to obtain information about the details of artillery maneuvers carried out by Italian warships at points close to the French border, but it has been observed that Italian warships are very active in the region and undertake the defense of the port from the sea route.

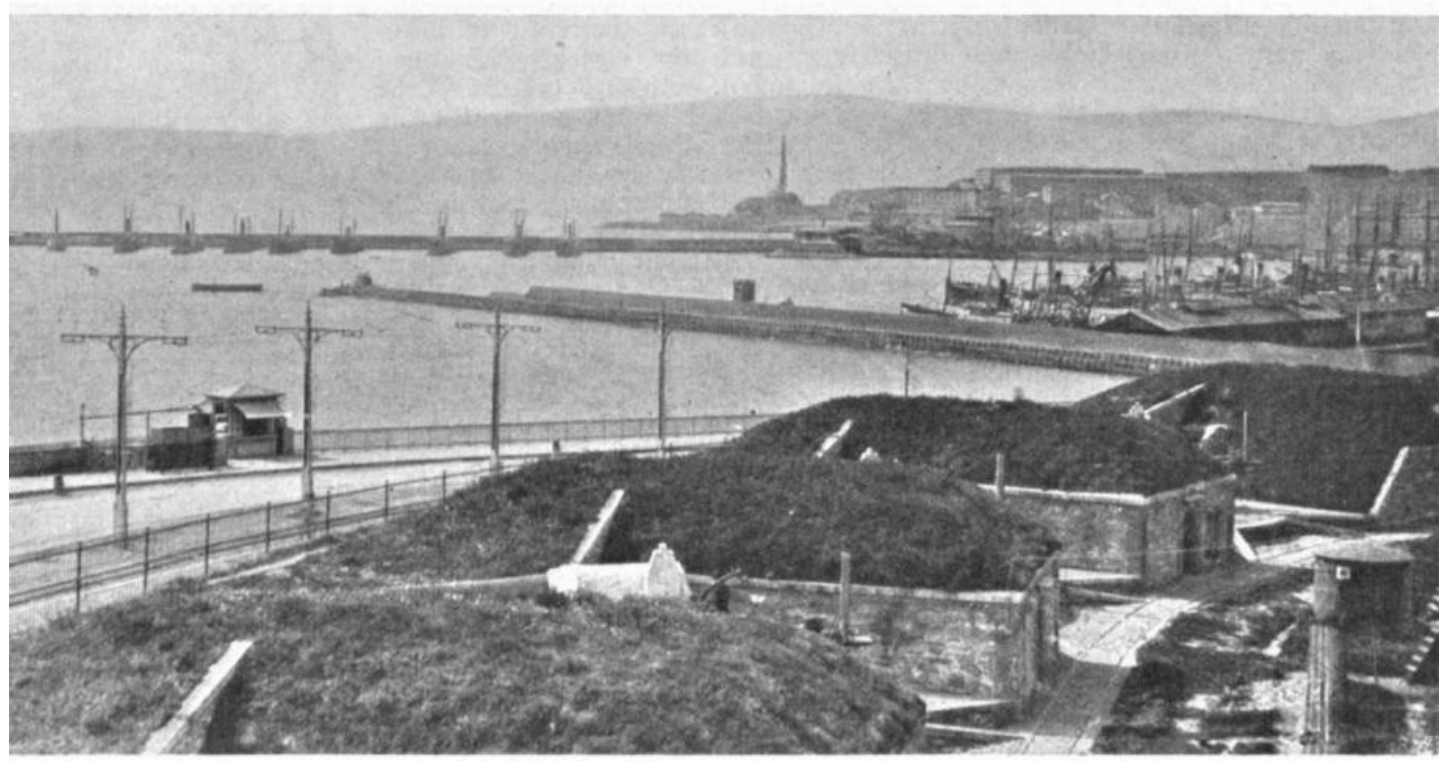

Illustration 3: Fortifications in Genoa Port ${ }^{18}$

When it is stated in the reports that there are seven docks belonging to the Ansoldo company in the port, it is stated that two warships belonging to the Italian navy were built in the shipyard and since there is plenty of coal in the port, the coal supply for Italian warships continues without any problems. ${ }^{19}$ On the other hand, consulate, who was of the opinion that the region was not a

${ }^{15}$ DTA, Bahriye Nezareti Kataloğu, Dosya No: 597, Sayfa No: 23631, Lef: 1, 26 Mart 1914.

${ }^{16}$ DTA, Bahriye Nezareti Kataloğu, Dosya No: 597, Sayfa No: 23631, Lef: 1, 26 Mart 1914.

${ }^{17}$ DTA, Bahriye Nezareti Kataloğu, Dosya No: 597, Sayfa No: 23631, Lef: 2, 26 Mart 1914.

${ }^{18}$ Österreichs Illustrierte Zeitung, "Ein Sperrforts im Hafen von Genua", Sayfa No: 896, 27 Haziran 1915.

${ }^{19}$ DTA, Bahriye Nezareti Kataloğu, Dosya No: 597, Sayfa No: 23631, Lef: 1-2, 26 Mart 1914.

\author{
History Studies \\ www.historystudies.net
}


suitable place for the healthy operation of radio-telegraph stations due to its mountainousness, said that British and German warships also visited the port, and that Genoa was a strategically important location in the west of the Mediterranean, after the French port of Marseille. ${ }^{20}$ While there was no information in the reports about the classes of the ships under construction at the shipyard in Genoa, there was no information about the number of warships stationed in the port, and it was emphasized that Genoa's proximity to the city of La Spezia and that it is possible to shift forces from this region in case of war. While there is no information in the Consulate reports that the Italian navy placed the port of Genoa, together with the naval power of the German and Austro-Hungarian Empire, in a very important place in the war strategy it planned against the French navy in the west of the Mediterranean, however, great importance was attributed to the port for the Italian's Mediterranean strategy.

\title{
Conclusion
}

The Italian navy was able to reach a higher level than other navies by completing the modernization in the Mediterranean in the fastest way in the twentieth century. While especially the reduction of the military power of the British navy on the island of Malta brought the influence of the Italian navy in the east of the Mediterranean to an undisputed position, the rivalry with the French navy in the west of the Mediterranean was important in determining the new balances in the Mediterranean. Italy, which made an alliance with Germany and the Austro-Hungarian Empire in the Mediterranean before the First World War, planned to cut off the connection of the French navy with Algeria by acting jointly with the naval forces of both states and to prevent this navy from helping the British navy in the North Sea. In this planning, the biggest burden of the war in the Mediterranean Sea was undertaken by the ports of Italy close to the coasts of France, and in this respect, the port of Genoa had a very strategic importance. From the point of view of the Ottoman Empire, although it had little to do with the western part of the Mediterranean, especially the Union and Progress administration was closely following a new initiative of the Italian navy in the Aegean Sea and the Eastern Mediterranean, since the Tripoli War had just ended. As of the first half of 1914, when the German influence in the Ottoman bureaucracy was not yet fully formed, the Ottoman Empire, which considered it more appropriate to remain neutral in a struggle that might occur in the west of the Mediterranean, nevertheless followed the developments in the region.

As a result, it was concluded that although it was protected by the Italian navy, the fortifications of the Port of Genoa would be ineffective against the firepower of the French Navy and that this port would lose its military importance in the campaign against France by the Italian navy over time. Although they were oppressed by the Germans, the Italians saw fit to wait for the end of the modernization program, which would last until 1920, for a full-scale struggle with the French navy and declared their neutrality during the First World War. The Italian navy, which would bear the main burden in a struggle with the French navy, reviewed its alliance with the Germans in the future and decided not to participate in the operation to be carried out in the west of the Mediterranean. As a result, the strategic importance of the port of Genoa was also eliminated in the struggle to be carried out by the German, Austro-Hungarian and Italian navies against the French Navy in the west of the Mediterranean Sea. Although we need Italian resources to make a more comprehensive assessment, it has been concluded that the decisions taken by the Italian military planners were wiser and that the port of Genoa, in particular, could not compete with the firepower of the French navy.

${ }^{20}$ DTA, Bahriye Nezareti Kataloğu, Dosya No: 597, Sayfa No: 26331, Lef: 2, 26 Mart 1914.

\author{
History Studies \\ www.historystudies.net
}




\section{REFERENCES}

\section{Archive}

Deniz Tarihi Arşivi, Bahriye Nezareti Kataloğu, Sayfa No: 23631, Lef: 1-2, 26 Mart 1914.

Politisches Archiv des Auswärtigen Amts, RZ 201 /7835, Sayfa No: 28-29, 28 Şubat 1912.

Politisches Archiv des Auswärtigen Amts, RZ 201 /7835, Sayfa No: 38-46, 12 Nisan 1912-21 Mayis 1912.

Politisches Archiv des Auswärtigen Amts, RZ 201 /7835, Sayfa No: 61-62, 8 Haziran 1912.

Politisches Archiv des Auswärtigen Amts, RZ 201 /8091, Sayfa No: 27, 10 Haziran 1912.

Politisches Archiv des Auswärtigen Amts, RZ 201 /7835, Sayfa No: 107, 8 Mart 1913.

Politisches Archiv des Auswärtigen Amts, RZ 201 /8091, Sayfa No: 23, 21 Mayıs 1913.

Politisches Archiv des Auswärtigen Amts, RZ 201 /7835, Sayfa No: 138, 13 Aral1k 1913.

Bundesarchiv, Militärarchiv; Nachlasse und Sammlungen, Dosya No: 156-1, Sayfa No: 8, 2 Aralık 1912.

\section{Secondary Sources}

Dan Van der Vot, Dünyayı Değiştiren Gemi: Goeben'in 1914'de Çanakkale Boğazı'na Kaçışı, Ali Cevat Akkoyunlu (Çev.), Alfa Yayınevi, İstanbul 2013.

Das Interessante Blatt, "Blockade der Küst Montenegros”, Sayfa No: 1, 10 Nisan 1913.

Das Interessante Blatt, "Der Beschluß der Mächte über die Flottendemonstration”, Sayfa No: 11, 10 Nisan 1913.

Illustrierte Kronen Zeitung, "Der Italienische Ueberfall auf der Hafenstadt Beirut", Sayfa No: 1, 28 Şubat 1912.

Mielke, Otto; Torpedoboots-Zerstörer-Scharfschütze: Vom Seekrieg im Mittelmeer 1914-1918, Maximilian Verlag, Hamburg 1998.

Österreichs Illustrierte Zeitung, "Ein Sperrforts im Hafen von Genua”, Sayfa No: 896, 27 Haziran 1915.

Sondhaus, Lawrance; The Great War at Sea: A Naval History of the First World War, Cambridge University Press, UK 2014.

Sondhaus, Lawrance; The Naval Policy of Austria-Hungary 1987-1918: Navalism, Industrial Development and Politics of Dualism, Purdue University Press, 1994.

Halpern, Poul G.; The Mediterranean Naval Situation 1908-1914, Harward University Press, USA 1971.

Karataş, Nuri; "Askeri ve Siyasi Yönleriyle İtalyan Donanmasının Çanakkale Boğazı Harekatı (18 Nisan 1912)", Akademik Bakış, Cilt: 6, Sayı: 12, 2013, ss. 81-109.

Kılıç, Sezen; Trablusgarp Savaşı'nda İtalyan Donanmasının Çanakkale Boğazı Harekatı (Alman Belgelerine Göre), Türk Tarih Kurumu Yayınları, Ankara 2018.

Kurtcephe, İsrafil; Türk-İtalyan İlişkileri (1911-1916), Türk Tarih Kurumu Yayınları, Ankara 1995. 


\section{Appendices}

Appendice 1: Italy's New Naval Program Against France (Germany's Rome Naval Attaché Report) ${ }^{21}$

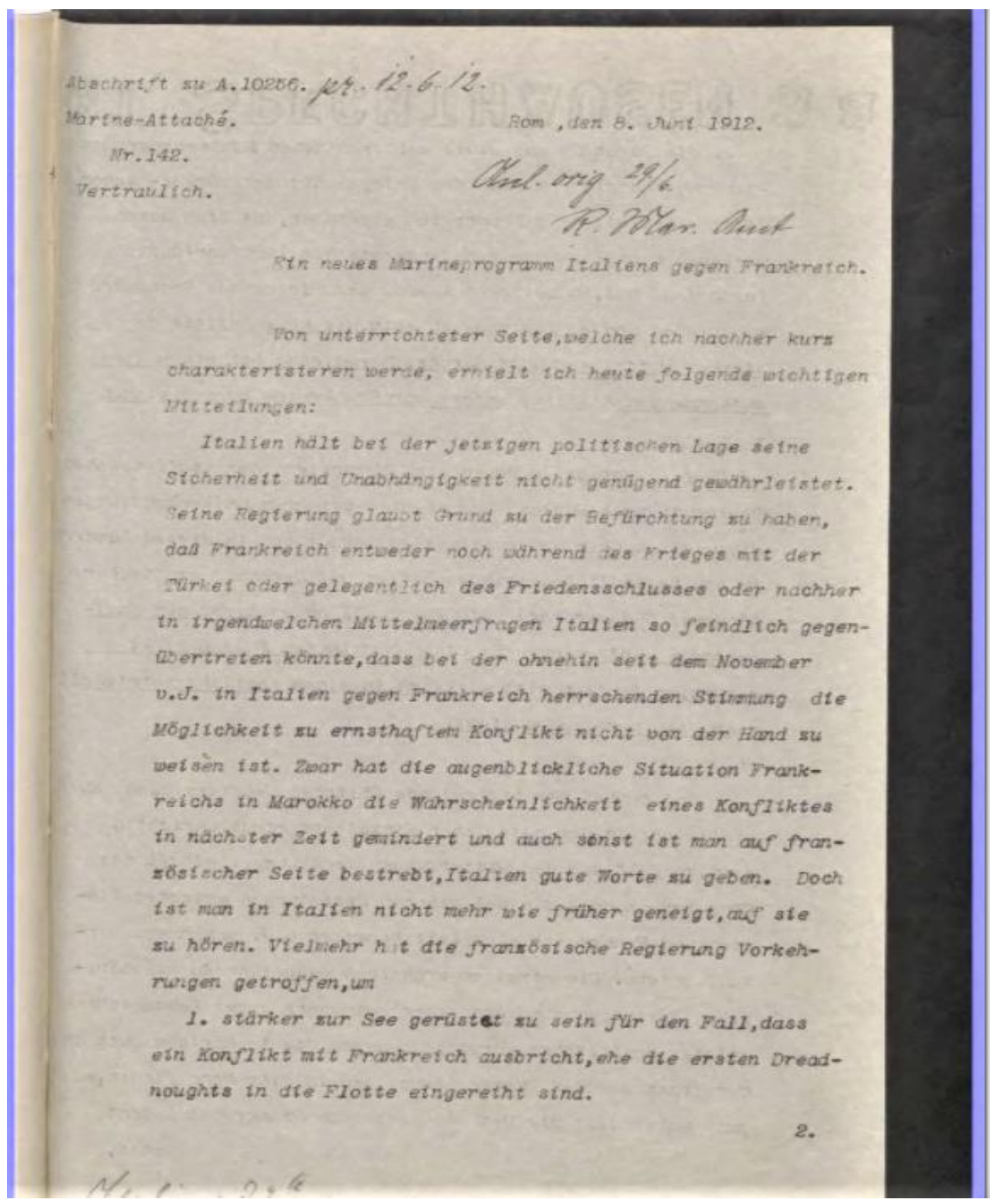

${ }^{21}$ Politisches Archiv des Auswärtigen Amts, RZ 201/ 7835, Sayfa No: 61, 8 Haziran 1912. 
Appendice 2: Italy's New Naval Program Against France (Germany's Rome Naval Attaché Report) ${ }^{22}$

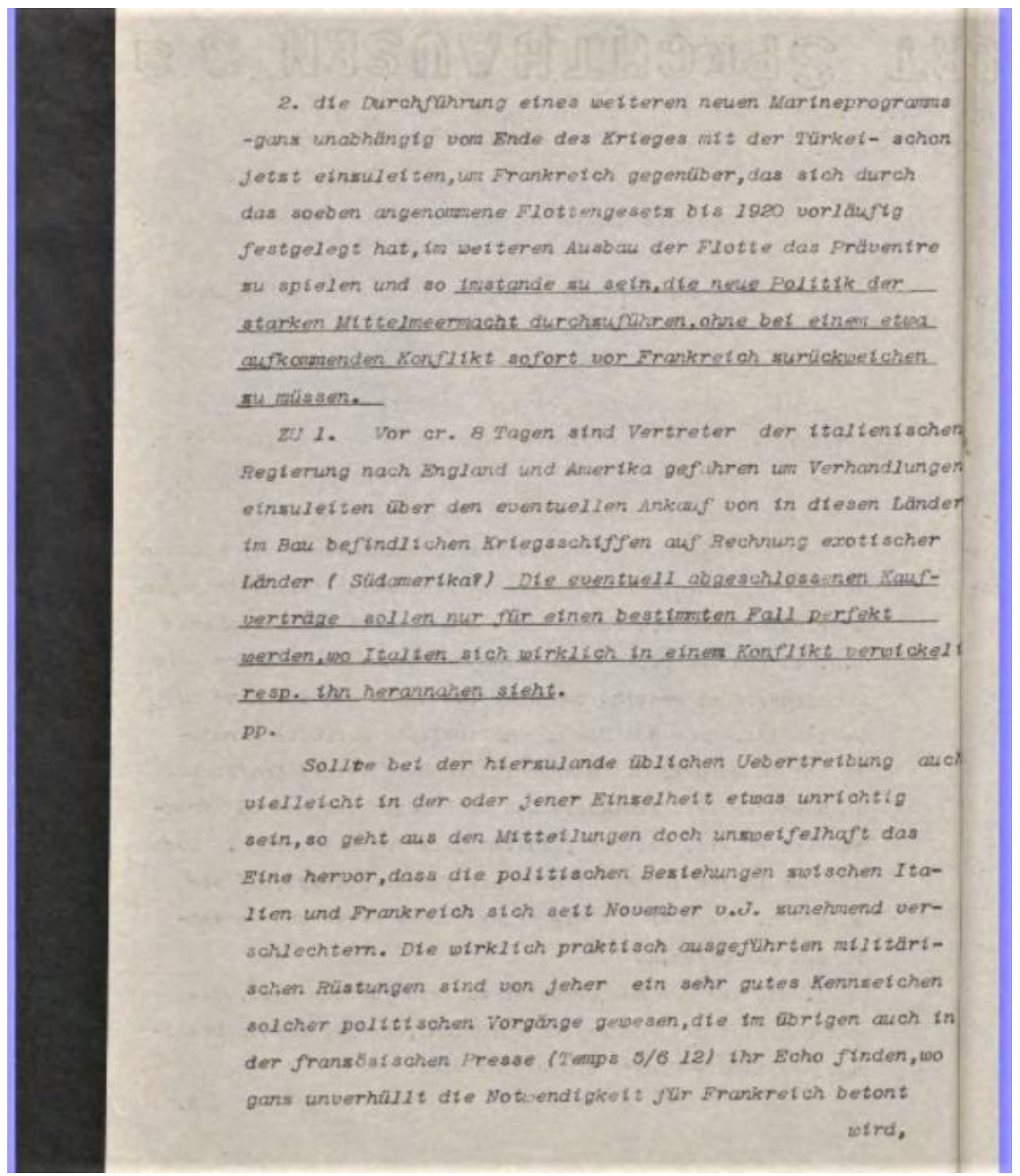

${ }^{22}$ Politisches Archciv des Auswärtiges Amts, RZ 201/ 7835, Sayfa No: 62, 8 Haziran 1912. 